\title{
Application of Geogrids in Stabilizing Rail Track Substructure
}

\author{
Syed Khaja Karimullah Hussaini* and Kumari Sweta \\ Railway Engineering, Department of Civil and Environmental Engineering, Indian Institute of Technology Patna, Patna, India
}

OPEN ACCESS

Edited by:

Eduardo Cabrita Fortunato, National Laboratory for Civil Engineering, Portugal

Reviewed by:

Ruilin You,

China Academy of Railway

Sciences, China

Sujit Kumar Dash,

Indian Institute of Technology Kharagpur, India

*Correspondence:

Syed Khaja Karimullah Hussaini hussaini@iitp.ac.in

Specialty section:

This article was submitted to Transportation and Transit Systems,

a section of the journa

Frontiers in Built Environment

Received: 21 August 2019 Accepted: 11 February 2020

Published: 25 February 2020

Citation:

Hussaini SKK and Sweta K (2020) Application of Geogrids in Stabilizing

Rail Track Substructure.

Front. Built Environ. 6:20. doi: 10.3389/fbuil.2020.00020
Large-scale direct shear tests were conducted to assess the performance of geogrid-reinforced ballast-sub-ballast interface followed by triaxial tests to explore the deformation and degradation response of geogrid-reinforced ballast under cyclic loading. While the direct shear testing was performed at applied normal stresses $\left(\sigma_{n}\right)$ ranging from 20 to $100 \mathrm{kPa}$ and rate of shearing $\left(S_{r}\right)$ from 2.5 to $10.0 \mathrm{~mm} / \mathrm{min}$, the cyclic triaxial tests were performed to capture the role of loading frequency $(f)$ ranging from 10 to $40 \mathrm{~Hz}$. Fresh granite ballast and sub-ballast with mean particle size $\left(D_{50}\right)$ of 42 and $3.5 \mathrm{~mm}$, and five geogrids having different aperture shapes and sizes $(A)$ were used in this study. The tests results indicated that the behavior of ballast-sub-ballast interface is highly influenced by $\sigma_{n}$ and $S_{r}$. The friction $(\varphi)$ and dilation angles $(\psi)$ of unreinforced and geogrid-reinforced ballast-sub-ballast interface is found to reduce from 67.96 to $47.82^{\circ}$ and 14.56 to $3.34^{\circ}$ with the increase in $\sigma_{n}$ and $S_{r}$. Marsal's Breakage $\left(B_{g}\right.$ : an index to quantify the breakage of ballast) of unreinforced ballast was found to increase from 2.84 to $6.69 \%$ with the increase in $\sigma_{n}$ and $S_{r}$. However, the inclusion of geogrids significantly enhanced the friction angle $(\varphi)$, reduced the extent of dilation angle $(\psi)$, and minimized $B_{g}$. The interface efficiency factor $(\alpha)$ and $B_{g}$ were found to be a function of $A / D_{50}$ ratio. Accordingly, a model is developed using multiple linear regression analysis to predict the values of $\varphi, \psi$, and $B_{g}$ in terms of the input parameters $\sigma_{n}, S_{r}$, and $A / D_{50}$ ratio. The results from triaxial tests indicate the deformation and degradation behavior of ballast under cyclic loading conditions to be influenced by the loading frequency $(f)$. The extent of $I_{d}$ and $S_{V}$ of unreinforced ballast increases from 5.48 to $28.32 \mathrm{~mm}$ and 20.13 to $45.40 \mathrm{~mm}$ with the increase in $f$. The value of $B_{g}$ increased from 4.3 to $11.69 \%$ when the value of $f$ was increased from 10 to $40 \mathrm{~Hz}$. Similarly, the extent of lateral and vertical deformation of ballast was found to be a function of $A / D_{50}$ ratio.

Keywords: geosynthetics, ballast-sub-ballast interface, direct shear test, cyclic loading, friction angle $(\varphi)$, settlement $\left(\mathbf{S}_{\mathrm{v}}\right)$, loading frequency $(\mathfrak{f})$, process simulation test (PST) apparatus

\section{INTRODUCTION}

Railways are one of the most economical modes of transportation for moving freight as well as passengers from one place to another. With the rapid increase in population and the associated traffic congestion on highways, the demand for high-speed railway lines is on rise. However, the inherent effect of the introduction of high-speed trains is to induce additional cyclic stresses on the substructure of a railway track that comprises mainly of ballast and sub-ballast layers. Ballast distributes the applied train load to the sub-ballast layer at an acceptable level while maintaining the track alignment and allowing the quick drainage of water. On the other hand, the sub-ballast 
reduces the extent of stress being transferred to the soil beneath and also acts as a filter medium thereby preventing the upward migration of subgrade soil into the ballast layer. However, due to continuous passage of trains, ballast being unbound in nature undergoes a significant amount of lateral deformation and particle degradation which directly contributes to track settlement. The excessive deformation and degradation of ballast leads to track misalignment that calls for either the imposition of speed restrictions or the conduction of costly track maintenance operations. In this view, the railway organizations around the world have recently started using the geogrids for stabilizing the railway tracks. In practice, the geogrids are generally placed at the bottom of ballast layer (i.e., at ballast-sub-ballast interface) so that the same will not obstruct the track maintenance process. Once in place, geogrids generates non-displacement boundary condition that limits the lateral movement of ballast that subsequently reduces vertical settlement and deformation of ballast.

Realizing the importance of geogrids in rail track application, several researchers have studied the role of geogrids on coarse granular medium under direct shear conditions (Lee and Manjunath, 2000; Liu et al., 2009; Palmeira, 2009; Anubhav and Basudhar, 2010, 2013; Hussaini et al., 2012; Indraratna et al., 2012; Moraci et al., 2014; Sayeed et al., 2014; Biabani and Indraratna, 2015; Liu and Martinez, 2015; Vieira et al., 2015; Choudhary and Krishna, 2016; Liu F.-Y. et al., 2016; Liu S. et al., 2016; Afzali-Nejad et al., 2017; Guler and Khosrowshahi, 2017; Mvelase et al., 2017; Chen et al., 2018; Sweta and Hussaini, 2018, 2019a; Mirzaalimohammadi et al., 2019). Liu et al. (2009) have determined the shear behavior of granular soils stabilized with PET-yarn geogrids. On the other hand, Makkar et al. (2017) have evaluated the behavior of sand when reinforced with geogrid in three dimensional forms. Biabani and Indraratna (2015) have investigated the behavior of sub-ballast when stabilized with geogrids and geomembranes. Indraratna et al. (2012) and Hussaini et al. (2012) have explored the shear behavior of various ballast-geogrid interfaces at constant shearing rate of 2.5 $\mathrm{mm} / \mathrm{min}$. Sweta and Hussaini $(2018,2019 \mathrm{a})$ have evaluated the shear behavior of ballast at different applied normal stresses and rates of shearing when stabilized with various geogrids. Similarly, several studies have highlighted the benefits of geogrids in stabilizing ballast under cyclic loading conditions (Bathurst and Raymond, 1987; Matharu, 1994; Brown et al., 2007; Indraratna et al., 2007, 2013, 2015; Mishra et al., 2014; Hussaini et al., 2015a,b, 2016; Biabani et al., 2016; Nimbalkar and Indraratna, 2016). Shin et al. (2002) highlighted the beneficial effect of reinforcement in reducing settlement when a layer of geogrid and geotextiles was placed at the interface of the subgrade and sub-ballast layer. Moreover, Nimbalkar and Indraratna (2016) have evaluated the benefits of inclusion of geosynthetics and rubber shock mats in the critical section of track through a field trial. Indraratna et al. (2015) and Biabani et al. (2016) have investigated the behavior of geocell-reinforced subballast at different frequencies under cyclic loading conditions. Navaratnarajah and Indraratna (2017) have assessed the use of rubber mats in improving the deformation and degradation behavior ballast at different frequencies and axle load. Indraratna et al. (2013) and Hussaini et al. (2015b) are the only studies that have captured the influence of geogrid aperture size $(A)$ in stabilizing the railway ballast under cyclic loading conditions at a constant loading frequency $(f)$ of $20 \mathrm{~Hz}$. In addition, there are several studies that have shown the effect of loading frequency $(f)$ on the behavior of unreinforced ballast under various cyclic loading conditions (Indraratna et al., 2010; Thakur et al., 2013; Sun et al., 2014, 2019). However, the role of geogrids in stabilizing railway ballast at different loading frequencies $(f)$ has not been yet studied. Similarly, there are very limited studies that describe the influence of applied normal stress $\left(\sigma_{n}\right)$ and rates of shearing $\left(S_{r}\right)$ on various ballast-geogrid-sub-ballast interfaces under direct shear conditions. Moreover, a rail track under operating conditions may be subjected to different shearing rates depending upon the magnitude of cyclic stress and the train speed. In this context, a series of large-scale direct shear tests were carried out to study the influence of $\sigma_{n}$ and $S_{r}$ on ballast-geogridsub-ballast interface followed by large-scale cubical triaxial tests to determine the effect of loading frequency $(f)$ on ballast with and without geogrids.

\section{MATERIALS AND TESTING PROCEDURES}

\section{Materials}

Fresh granite particles and a mixture of sand and crushed granite were used as ballast and sub-ballast, respectively. The particle size distributions (PSD) of ballast and sub-ballast used in the present study were as per the standards specified by Indian railways (IRSGE, 2004; RDSOGE, 2007; Figure 1). The particle size characteristics of ballast and sub-ballast are presented in Table 1. The maximum $\left(D_{\max }\right)$ and mean diameters $\left(D_{50}\right)$ of sub-ballast were 20 and $3.5 \mathrm{~mm}$ and that of ballast were 65 and

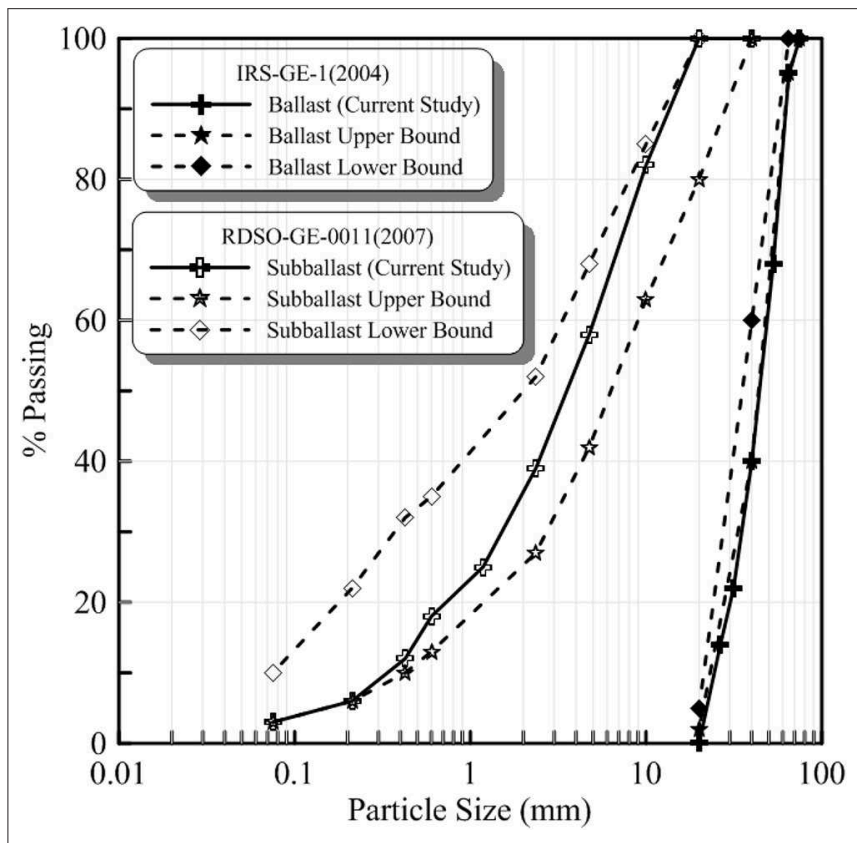

FIGURE 1 | Particle size distributions of ballast and sub-ballast used in this study. 
$42 \mathrm{~mm}$, respectively. Five types of geogrids were used in the current study to stabilize the rail road ballast. These geogrids have different aperture shapes and sizes. The physical characteristics and technical specifications of geogrids (labeled G1 to G5) used in the present study are described in Table 2.

\section{Direct Shear Tests}

A series of shear tests were performed using large-scale direct shear apparatus, having plan dimension of $450 \times 450 \mathrm{~mm}$ and overall depth of $300 \mathrm{~mm}$. The apparatus consists of two square boxes; the lower box is fixed in position while the upper box is allowed to move. The apparatus can allow application of normal stress and can capture the shear stresses up to $300 \mathrm{kN} / \mathrm{m}^{2}$ and can allow shear displacements up to $100 \mathrm{~mm}$. The dimensions of the apparatus and the capacity of load cells have been suitably selected to explicitly test coarse granular materials like railway ballast at high normal loading and strain rates. Figure $2 \mathbf{A}$ shows the schematic illustration of large-scale direct shear apparatus.

The specimen preparation involves the mixing of sieved ballast and sub-ballast separately in a required proportion conforming to the PSDs as specified in Figure 1. The lower box of shear apparatus was filled with a predetermined quantity of sub-ballast and then compacted in two layers with the help of a vibrating plate to attain a required density $\left(\gamma_{s b}\right)$ of $2,000 \mathrm{~kg} / \mathrm{m}^{3}$ which is the representative of typical field conditions. Then, the ballast is filled in the upper shear box and compacted in two layers with same vibrating plate to attain a field density $\left(\gamma_{b}\right)$ of 1,470 $\mathrm{kg} / \mathrm{m}^{3}$. In case of reinforced samples, a layer of geogrid is installed at the interface of two shear boxes and fixed with the clamping screws after the compaction of sub-ballast in lower shear box. To reduce the extent of particle breakage during vibration, a $7 \mathrm{~mm}$ thick rubber pad was placed beneath the vibrating plate. Tests were conducted at different applied normal stresses $\left(\sigma_{n}\right)$ ranging from 20 to $100 \mathrm{kPa}$ which is representative of typical track conditions under low confinement and shearing rates $\left(S_{r}\right)$

TABLE 1 | Grain size characteristics of ballast and sub-ballast.

\begin{tabular}{lccccccc}
\hline Material & $\begin{array}{c}\boldsymbol{D}_{\text {max }} \\
(\mathbf{m m})\end{array}$ & $\begin{array}{c}\boldsymbol{D}_{\mathbf{1 0}} \\
(\mathbf{m m})\end{array}$ & $\begin{array}{c}\boldsymbol{D}_{\mathbf{3 0}} \\
\mathbf{( \mathbf { m m } )}\end{array}$ & $\begin{array}{c}\boldsymbol{D}_{\mathbf{6 0}} \\
\mathbf{( m m})\end{array}$ & $\begin{array}{c}\boldsymbol{D}_{\mathbf{5 0}} \\
(\mathbf{m m})\end{array}$ & $\boldsymbol{C}_{\boldsymbol{u}}$ & $\boldsymbol{C}_{\boldsymbol{c}}$ \\
\hline Sub-ballast & 20 & 0.35 & 1.7 & 5.0 & 3.5 & 14.29 & 1.65 \\
Ballast & 65 & 22 & 32 & 48 & 42 & 2.18 & 0.97
\end{tabular}

ranging from 2.5 to $10.0 \mathrm{~mm} / \mathrm{min}$. The tests were carried out up to the horizontal displacement of $67.5 \mathrm{~mm}$ that represents a horizontal strain of $15 \%$.

\section{Triaxial Tests Using Process Simulation Test (PST) Apparatus}

A series of triaxial tests were carried out using large-scale process simulation test (PST) apparatus, consisting of a box of $950 \mathrm{~mm}$ length, $650 \mathrm{~mm}$ width, and $730 \mathrm{~mm}$ overall depth. The plan dimension of $950 \mathrm{~mm}$ represents the effective sleeper length that transfers the applied wheel load to the ballast beneath, as defined by Jeffs and Tew (1991) and Atalar et al. (2001). On the other hand, $650 \mathrm{~mm}$ represents the center-center spacing between the sleepers in the direction of rail. The mid portion of the two side walls parallel to rails (i.e., along the direction of passage of train) consists of five independent movable plates each measuring $650 \mathrm{~mm}$ in width and $75 \mathrm{~mm}$ in height. A small gap of $1 \mathrm{~mm}$ was provided to allow the free movement of plates in lateral direction. The maximum allowable lateral displacement of each plate is $100 \mathrm{~mm}$ that corresponds to a lateral strain $\left(\varepsilon_{3}\right)$ of $10.52 \%$. The apparatus used in the current study is similar to that used by Hussaini (2013) and Indraratna et al. (2013) but with five independently movable side walls on both the sides. The apparatus can be used to apply a vertical dynamic load of $200 \mathrm{kN}$ at frequencies of up to $50 \mathrm{~Hz}$. Figure 2B illustrates the schematic diagram of process simulation test apparatus.

The specimen preparation involved the placement of subballast (150 mm thick), comprising of crushed granite-sand mixture, in two layers of $75 \mathrm{~mm}$ each and their compaction with the help of a vibrating plate to attain a required density $\left(\gamma_{s b}\right)$ of $2,000 \mathrm{~kg} / \mathrm{m}^{3}$. This was overlain by a ballast layer of $380 \mathrm{~mm}$ that was placed in three equal layers and compacted to achieve a target field density $\left(\gamma_{b}\right)$ of $1,520 \mathrm{~kg} / \mathrm{m}^{3}$. It is to be mentioned here that in both the series of tests the ballast particles were painted with bright yellow spray paint in order to clearly distinguish the broken pieces of ballast from underlying sub-ballast. A railsleeper assembly (wooden sleeper: $900 \times 250 \times 150 \mathrm{~mm}$ ) was then placed over the compacted ballast and the spaces around the sleeper were filled with crib ballast. The rail section used was MR52 section, as used by the Indian Railways on most of the broad gauge tracks. In case of reinforced samples, a layer of geogrid was placed at the ballast-sub-ballast interface as done in case of direct shear test samples.

TABLE 2 | Physical characteristics and technical characteristics of geogrid used in the current study.

\begin{tabular}{|c|c|c|c|c|c|c|}
\hline Characteristics & Properties & G1 & G2 & G3 & G4 & G5 \\
\hline \multirow[t]{4}{*}{ Physical } & Material & PP & PP & PP & PP & PP \\
\hline & Aperture shape & Square & Triangular & Rectangular & Triangular & Square \\
\hline & Aperture size (MD/CMD) & $39 / 39$ & $46 / 46$ & $34 / 36$ & $69 / 69$ & $65 / 65$ \\
\hline & Rib thickness & $2.2 / 2.1$ & $1.2 / 1.2$ & $2.8 / 2.8$ & $2.2 / 2.2$ & $3.6 / 4.5$ \\
\hline Technical & $T_{\text {ult }}^{\mathrm{a}}(\mathrm{kN} / \mathrm{m})$ & 30 & 19 & 40 & 21 & 30 \\
\hline
\end{tabular}

a Ultimate Tensile Strength (manufacturer supplied values).

$M D$, machine direction; $C M D$, cross machine direction; PP, polypropylene. 
A

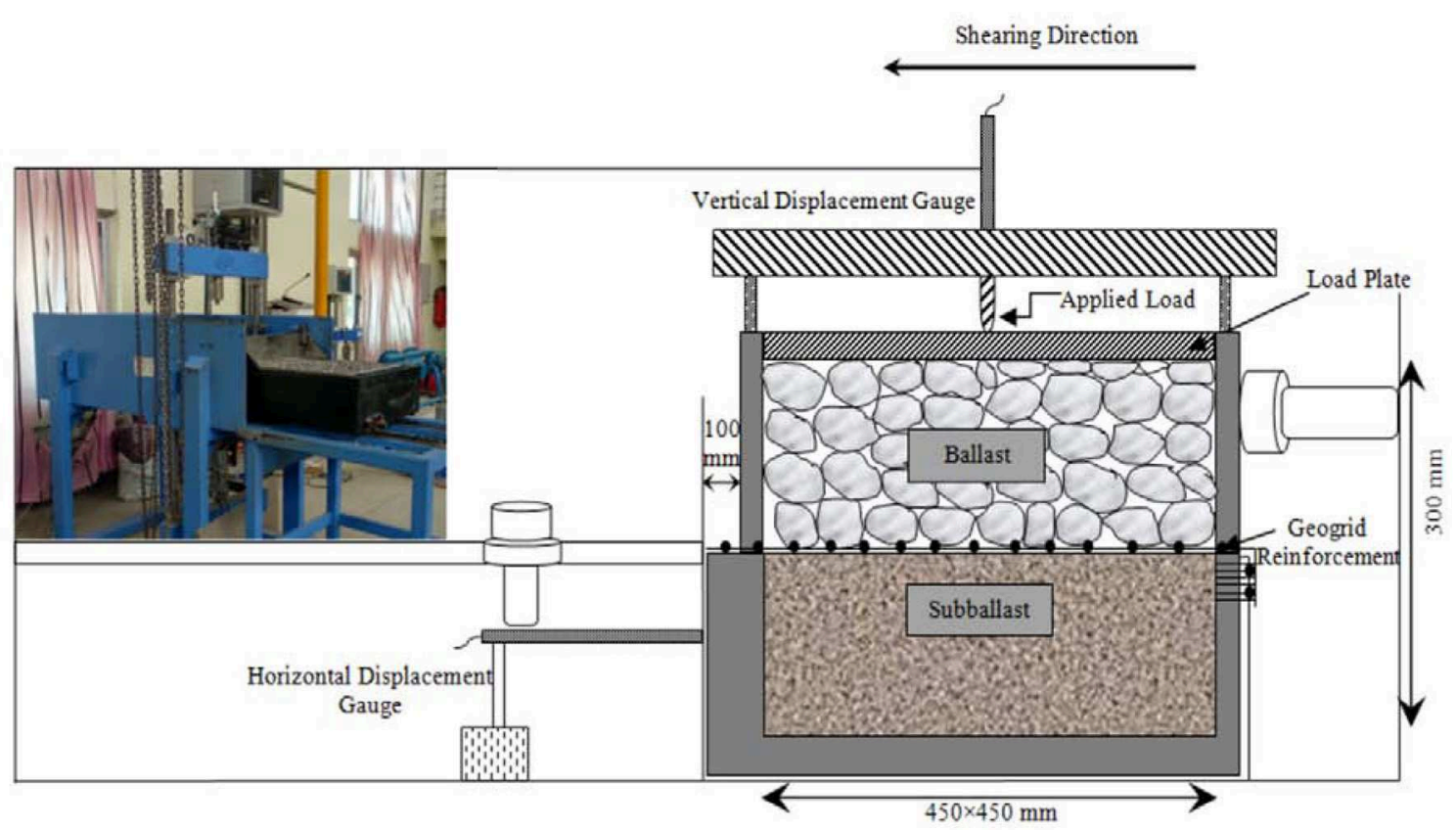

B

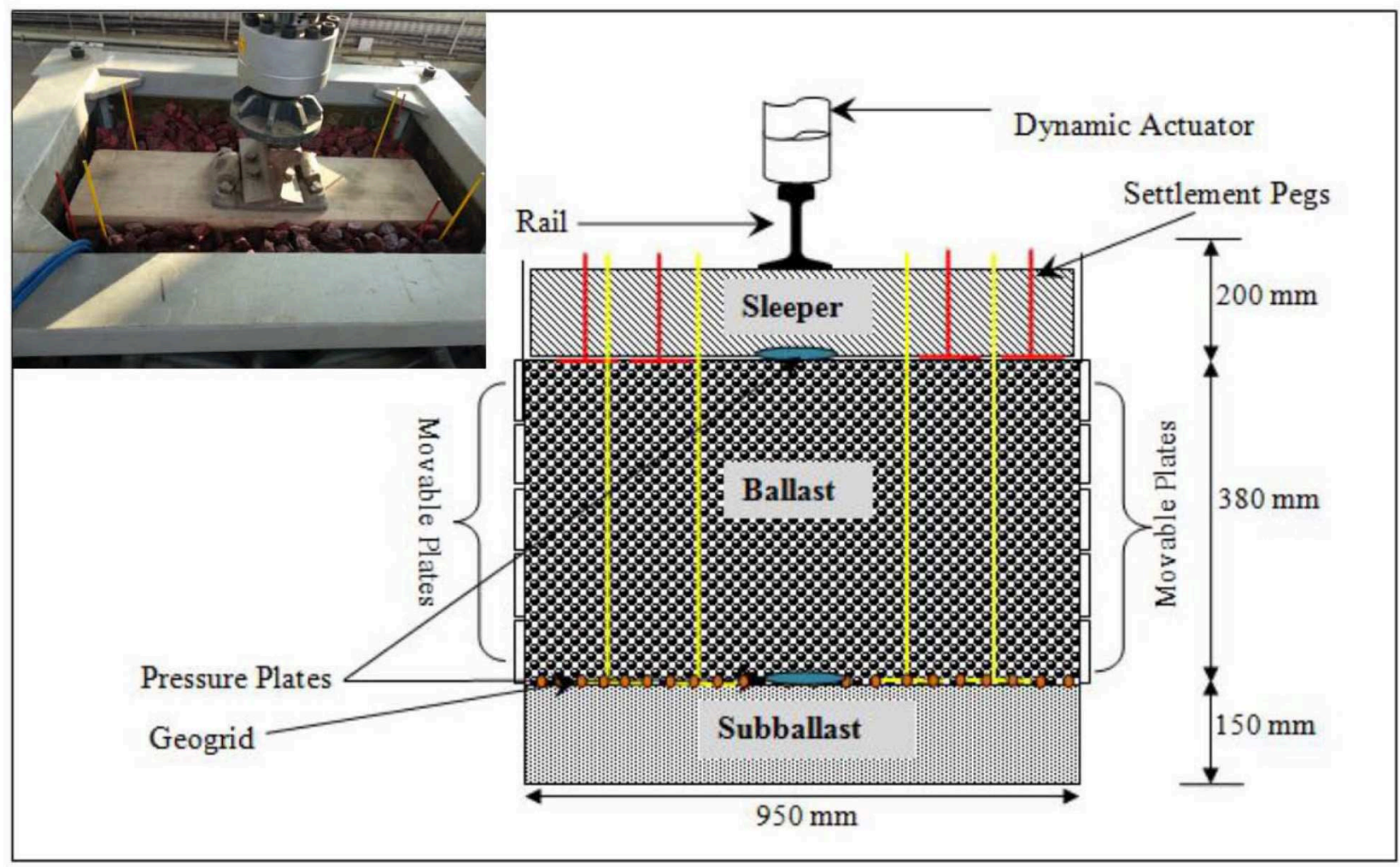

FIGURE 2 | Schematic illustrations of (A) direct shear apparatus and (B) process simulation test (PST) apparatus.

A cyclic vertical stress of $300 \mathrm{kPa}$ was applied onto the test specimen with the help of vertical dynamic actuator, and a confining pressure of $10 \mathrm{kPa}$ was applied onto the two side walls having five movable plates. It is well-known that the tendency of unbound ballast is to move laterally in outward direction (parallel to sleeper) under track operating conditions. Therefore, 
the shorter walls were allowed to move laterally and the other two longitudinal walls were kept fixed to mimic the plane strain conditions $\left(\varepsilon_{2}=0\right)$ in the direction parallel to rails (i.e., along the direction of passage of train), as was also adapted earlier by Hussaini (2013) and Indraratna et al. (2013). Two earth pressure cells were placed at sleeper-ballast and ballast-subballast interface to measure the vertical stresses during the test. The pressure cells used in the current study had the diameter of $230 \mathrm{~mm}$ and the thickness of $12 \mathrm{~mm}$.

Tests were conducted at loading frequencies of 10, 20, 30, and $40 \mathrm{~Hz}$ which is representative of higher train speeds $(\sim 73-$ $292 \mathrm{~km} / \mathrm{h}$, for an axle spacing of $2.02 \mathrm{~m}$ ) and up to 250,000 load cycles $(N)$. During the test, the lateral displacement of the movable plates and the vertical settlement of ballast were continuously recorded by the data acquisition system. The extent of vertical settlement was also recorded by placing four settlement plates at sleeper-ballast and ballast-sub-ballast interface. The test was halted at specific number of cycles to record the vertical settlement of ballast and sub-ballast layers. The ballast specimen was retrieved carefully and sieved after each test to evaluate the change in gradation and to quantify the breakage of particles owing to cyclic loading. Figure 2B shows the final arrangement of the test specimen ready for testing.

\section{RESULTS AND DISCUSSION}

\section{Friction Angle $(\varphi)$ of Ballast-Sub-Ballast Interface}

Figure $3 \mathbf{A}$ shows the variation of friction angle $(\varphi)$ with applied normal stress $\left(\sigma_{n}\right)$ for unreinforced ballast-sub-ballast interface and that reinforced with various geogrids at $S_{r}=5.0 \mathrm{~mm} / \mathrm{min}$. It is seen that the $\varphi$ of unreinforced ballast-sub-ballast interface reduces from 61.82 to $48.95^{\circ}$ as $\sigma_{n}$ increases from 20 to 100 $\mathrm{kPa}$. The decrease in $\varphi$ with the increase in $\sigma_{n}$ is primarily due to the suppression of dilation and also because of the enhanced breakage of particles (as will be described in the latter sections of the paper) at higher normal stresses. Similar to the behavior of unreinforced interface, the apparent friction angle $(\delta)$ of ballastsub-ballast interface when reinforced with geogrids $G 1$ and $G 2$ decreases from 66.02 to $50.97^{\circ}$ and 65.76 to $50.22^{\circ}$, respectively, as $\sigma_{n}$ increases from 20 to $100 \mathrm{kPa}$. A similar reduction in $\delta$ with the increase in $\sigma_{n}$ is observed for other rates of shearing $\left(S_{r}\right)$ but is not shown here for the sake of brevity. It is further observed that $\delta$ of all reinforced ballast-sub-ballast interfaces is greater than that of unreinforced interfaces (Figure 3A). For example, the insertion of geogrids $G 4$ and $G 5$ at ballast-subballast interface increases the values of $\varphi$ from 61.82 to $64.79^{\circ}$ and $62.56^{\circ}$, respectively.

Figure 3B depicts the variation of friction angle $(\varphi)$ with shearing rate $\left(S_{r}\right)$ of unreinforced ballast-sub-ballast interface and that reinforced with various geogrids at $\sigma_{n}=70 \mathrm{kPa}$. The value of $\varphi$ of unreinforced ballast-sub-ballast interface decreases from 51.98 to $49.93^{\circ}$ as $S_{r}$ is increased from 2.5 to 10.0 $\mathrm{mm} / \mathrm{min}$. The increasing rates of shearing have a similar effect on the friction angle of ballast-geogrid-sub-ballast interfaces. For example, the apparent friction angle $(\delta)$ of ballast-sub-ballast
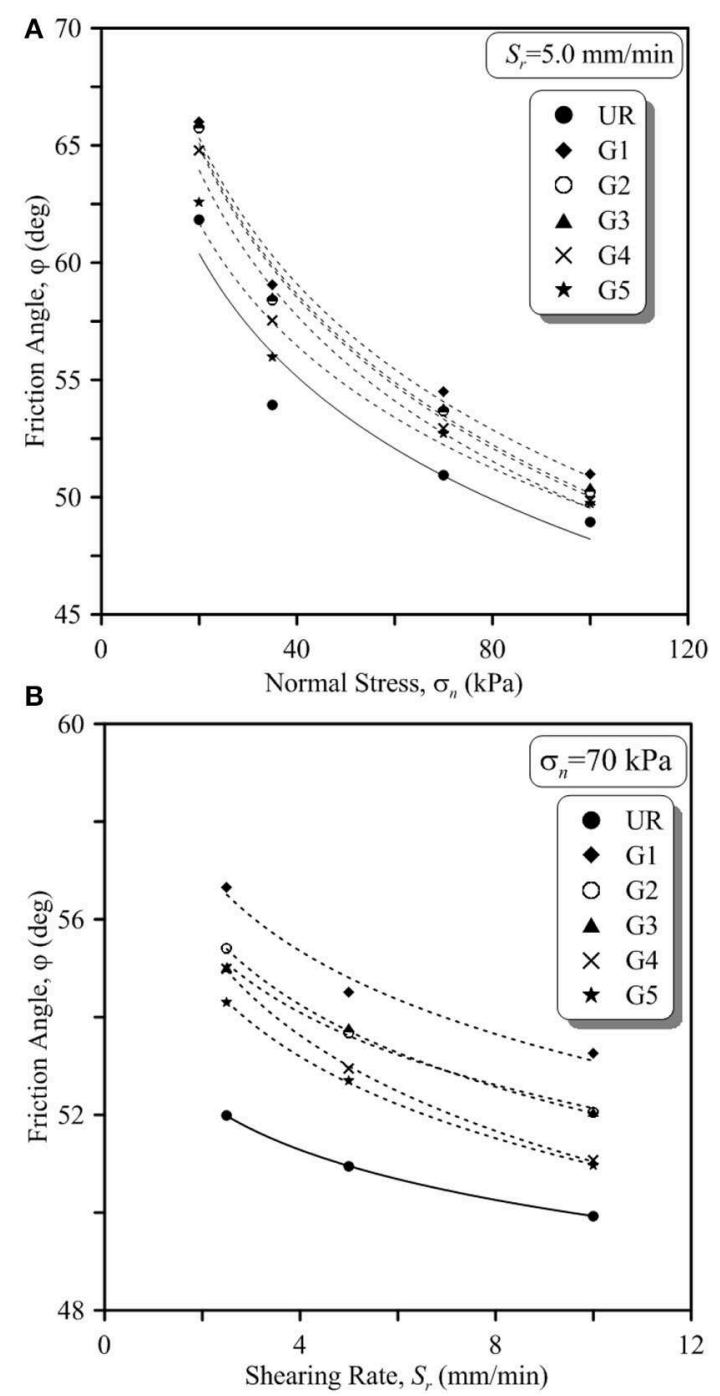

FIGURE 3 | Variation of friction angle of unreinforced and geogrid-reinforced ballast-sub-ballast with (A) applied normal stress at $S_{r}=5.0 \mathrm{~mm} / \mathrm{min}$ and (B) shearing rates at $\sigma_{n}=70 \mathrm{kPa}$.

reinforced with geogrid $G 4$ and G5 reduced from 54.98 to $51.53^{\circ}$ and 54.3 to $51^{\circ}$ as $S_{r}$ increased from 2.5 to $10.0 \mathrm{~mm} / \mathrm{min}$. The observation with respect to the variation of $\varphi$ with $S_{r}$ is in accordance with the studies conducted for ballast (Sweta and Hussaini, 2018) and sub-ballast (Biabani and Indraratna, 2015). In a practical sense, the reduced values of friction angles with the increase in shearing rates indicate the reduction in ballast performance with the increase in train speeds. However, it is seen that the geogrids enhance the friction angle of ballast-sub-ballast interface for all the applied shearing rates (Figure 3B), thereby highlighting their effectiveness in enhancing the ballast performance at higher train speeds. For instance, $\varphi$ of unreinforced ballast-sub-ballast interface increased from 51.98 to $56.66^{\circ}$ and $55.41^{\circ}$ when stabilized with geogrid $G 1$ and G2, respectively. 


\section{Dilation Angle $(\psi)$ of Ballast-Sub-Ballast Interface}

The dilation angle $(\psi)$ of ballast-sub-ballast is mainly associated with the rate of dilation and is computed as the ratio of change in vertical displacement $\left(d_{v}\right)$ to the change in horizontal displacement $\left(d_{h}\right)$ (Equation 1; Bolton, 1986; Simoni and Houlsby, 2006) and can be expressed as

$$
\psi=\frac{d\left(d_{v}\right)}{d\left(d_{h}\right)}
$$

Where $\psi$ is the dilation angle, $d\left(d_{v}\right)$ is the change in vertical displacement, $d\left(d_{h}\right)$ is the change in horizontal displacement.

Figure 4 shows the variation of peak dilation angle $(\psi)$ with peak friction angle $(\varphi)$ of unreinforced ballast-sub-ballast interface and that stabilized with geogrids for different values of $S_{r}$. As expected, dilation angle $(\psi)$ of both unreinforced and reinforced ballast-sub-ballast interface decreases with increasing values of $\sigma_{n}$. For example, the value of $\psi$ in case of unreinforced ballast-sub-ballast interface and that reinforced with $G 1$ is found to decrease from 14.56 to $8.51^{\circ}$ and 11.03 to $4.13^{\circ}$ as $\sigma_{n}$ increases from 20 to $100 \mathrm{kPa}\left(S_{r}=2.5 \mathrm{~mm} / \mathrm{min}\right)$. Likewise, for $S_{r}=5.0$ and $10.0 \mathrm{~mm} / \mathrm{min}$, the value of $\psi$ decreases from 12.89 to $7.74^{\circ}$ \& 10.38 to $3.89^{\circ}$ and 11.89 to $5.23^{\circ} \& 9.16$ to $4.78^{\circ}$, respectively. It is further revealed that dilation angle $(\psi)$ of both unreinforced and reinforced interface decreases with the increase in $S_{r}$. The value of $\psi$ of unreinforced ballast-sub-ballast and that reinforced with $G 1$ decreases from 14.56 to $11.89^{\circ}$ and 10.38 to $9.16^{\circ}$ as $S_{r}$ increases from 2.5 to $10.0 \mathrm{~mm} / \mathrm{min}\left(\sigma_{n}=20 \mathrm{kPa}\right)$. Likewise, for other normal stresses of 35,70 , and $100 \mathrm{kPa}, \psi$ decreases from 12.78 to $8.95^{\circ} \& 9.24$ to $8.00^{\circ}, 9.73$ to $7.42 \& 6.78$ to $6.34^{\circ}$, and 8.51 to $5.23^{\circ} \& 4.13$ to $3.35^{\circ}$, respectively. Figure 5 also establishes the role of geogrids in diminishing the extent of dilation. For instance, reinforcement of ballast-sub-ballast interface with geogrid $G 1$ reduces the dilation angle $(\psi)$ from 14.56 to $11.03^{\circ}\left(\sigma_{n}=20 \mathrm{kPa} ; S_{r}=2.5 \mathrm{~mm} / \mathrm{min}\right)$.

\section{Breakage of Ballast $\left(B_{g}\right)$ Under Shearing Conditions}

The influence of applied normal stress $\left(\sigma_{n}\right)$ and shearing rate $\left(S_{r}\right)$ on the breakage of ballast for both unreinforced and reinforced ballast-sub-ballast interface is shown in Figure 5. It is revealed that $B_{g}$ increases with the increase in $\sigma_{n}$ and $S_{r}$. For example, $B_{g}$ of unreinforced ballast increased from 3.33 to $5.26 \%$ as $\sigma_{n}$ increased from 20 to $100 \mathrm{kPa}$. Furthermore, the value of $B_{g}$ of unreinforced ballast increased from 3.41 to $5.72 \%$ as $S_{r}$ enhanced from 2.5 to $10.0 \mathrm{~mm} / \mathrm{min}\left(\sigma_{n}=35 \mathrm{kPa}\right.$; Figure 5A). A similar increase in $B_{g}$ is observed for geogrid-reinforced ballast-subballast interface. For instance, the ballast-sub-ballast interface when reinforced with geogrid $G 1$ and $G 2$, the value of $B_{g}$ increases from 2.49 to $3.49 \%$ and 2.56 to $3.56 \%$ as $\sigma_{n}$ increases from 20 to $100 \mathrm{kPa}$. Furthermore, for the applied normal stress of $35 \mathrm{kPa}$, the value of $B_{g}$ of ballast-sub-ballast interface reinforced with geogrid $G 1$ increases from 2.43 to $3.84 \%$ as $S_{r}$ increases from 2.5 to $10.0 \mathrm{~mm} / \mathrm{min}$. It is evident from Figure $\mathbf{5 B}$ that insertion of geogrids at ballast-sub-ballast interface diminishes the extent of $B_{g}$ in ballast. For example, in case of ballast reinforced with

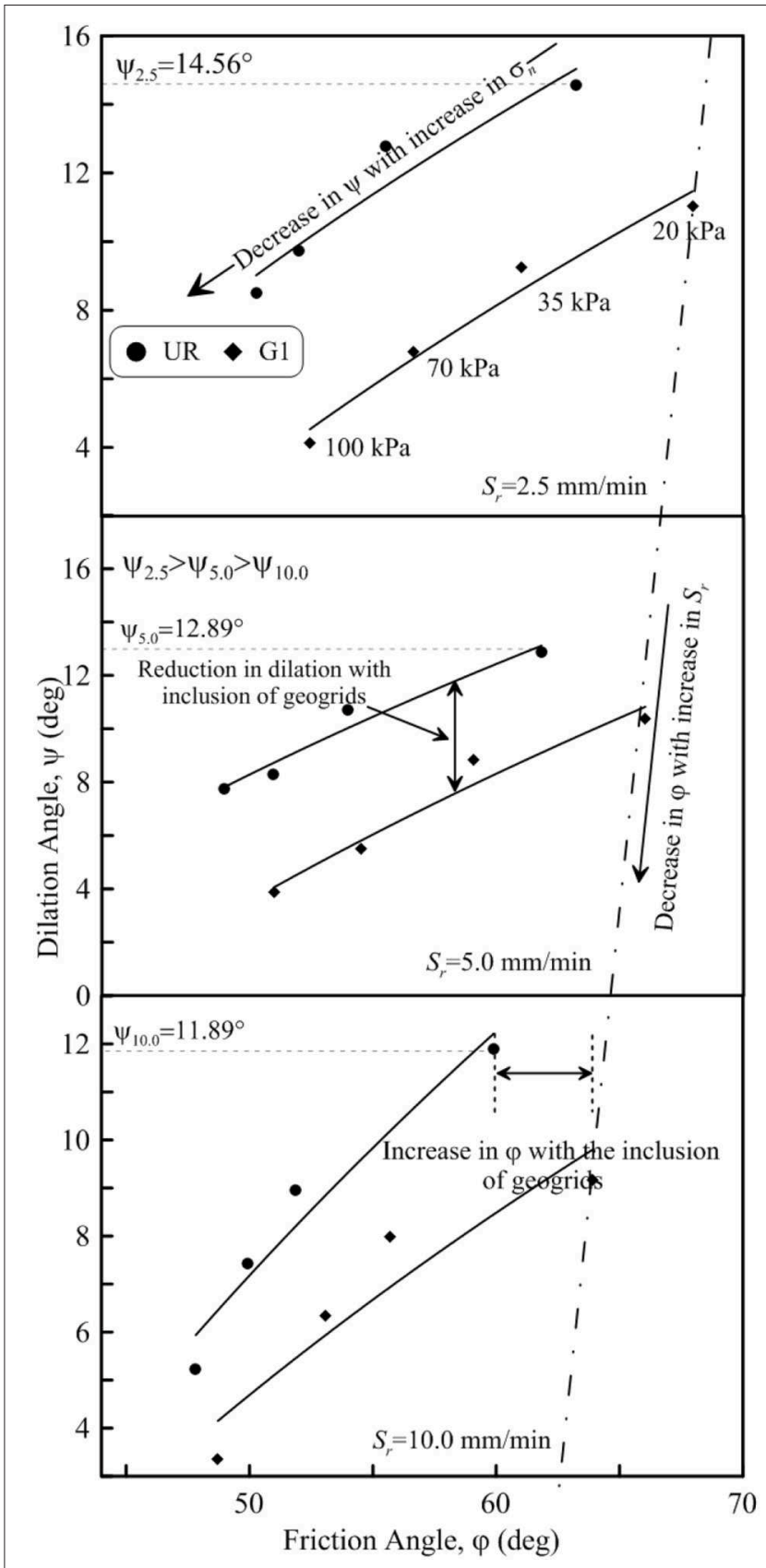

FIGURE 4 | Variation of dilation angle $(\psi)$ with peak friction angle $(\varphi)$ of unreinforced and geogrid-reinforced ballast-sub-ballast interface.

geogrid $G 4$ and $G 5$, the value of $B_{g}$ reduced from 3.85 to $3.10 \%$ and $3.31 \%$, respectively $\left(\sigma_{n}=35 \mathrm{kPa} ; S_{r}=5.0 \mathrm{~mm} / \mathrm{min}\right)$.

\section{Regression Models to Determine of Friction $(\varphi)$, Dilation Angles $(\psi)$, and Breakage $\left(B_{g}\right)$ of Ballast}

To emphasize the role of geogrid aperture size $(A)$ in enhancing the shear strength of ballast, the variation of interface efficiency factor $(\alpha)$ and ballast breakage $\left(B_{g}\right)$ with $A / D_{50}$ ratio for different 

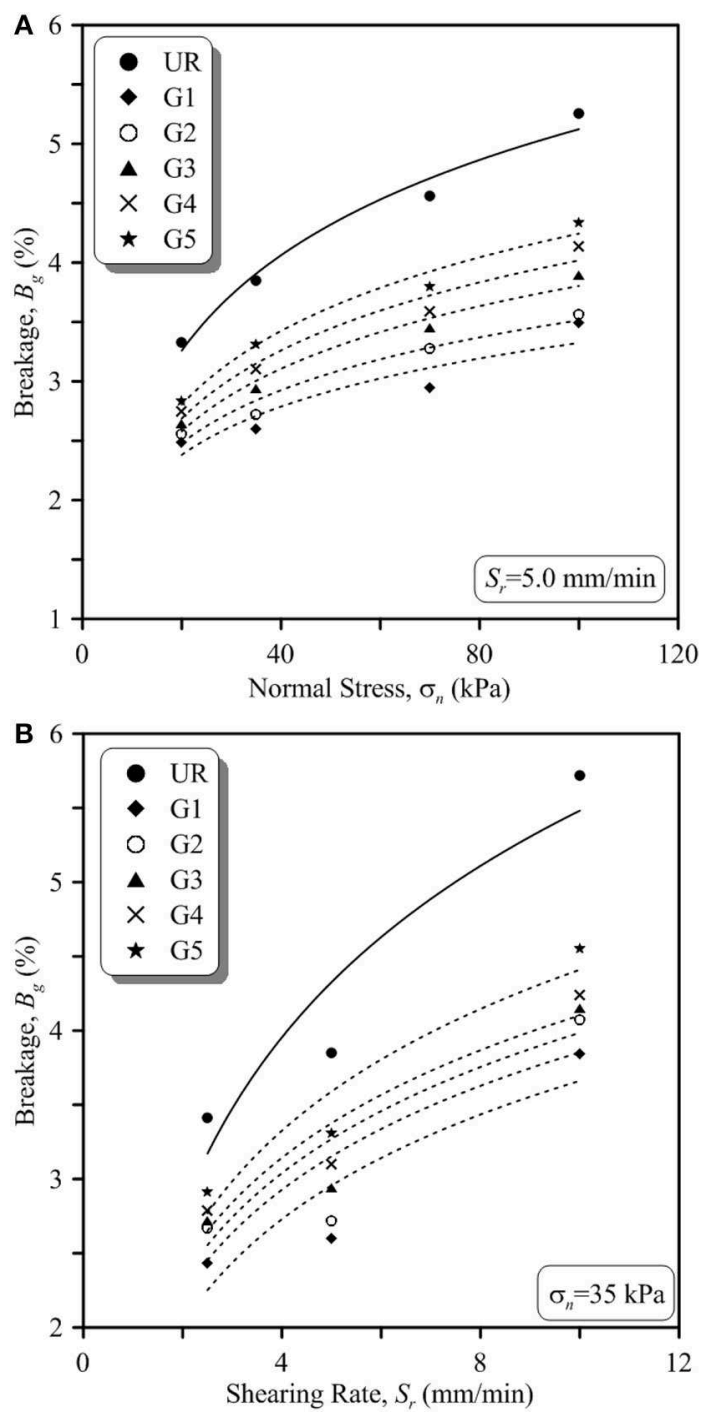

FIGURE 5 | Variation of breakage of unreinforced and geogrid-reinforced ballast with (A) applied normal stress at $S_{r}=5.0 \mathrm{~mm} / \mathrm{min}$ and $(\mathbf{B})$ shearing rates at $\sigma_{n}=35 \mathrm{kPa}$.

rates of shearing $\left(S_{r}\right)$ are shown in Figure 6. It is revealed from Figure 6 that as the value of $\alpha$ increases, the extent of $B_{g}$ decreases. For instance, $\alpha$ attains the maximum value of 1.22 and $B_{g}$ attains the minimum value of $2.75 \%$ at $A / D_{50}=0.93$ (G1) and then $\alpha$ decreases to 1.10 and $B_{g}$ increases to $3.15 \%$ at $A / D_{50}=1.54$ (G5) $\left(S_{r}: 2.5 \mathrm{~mm} / \mathrm{min}\right)$. Similarly, for $S_{r}=5.0$ and $10.0 \mathrm{~mm} / \mathrm{min}$, geogrid $G 1$ with an $A / D_{50}$ of 0.93 exhibits the maximum value of $\alpha$ of 1.19 and 1.15 which in turn exhibits the minimum breakage of 2.88 and $3.93 \%$, respectively. This signifies that by suitably selecting the geogrids, the value of $\alpha$ could be enhanced significantly and breakage of ballast particles could be minimized.

It is well-known that the behavior of ballast under track operating conditions is governed by axle load, confining pressure and the train speed. In a real rail track environment, axle load is

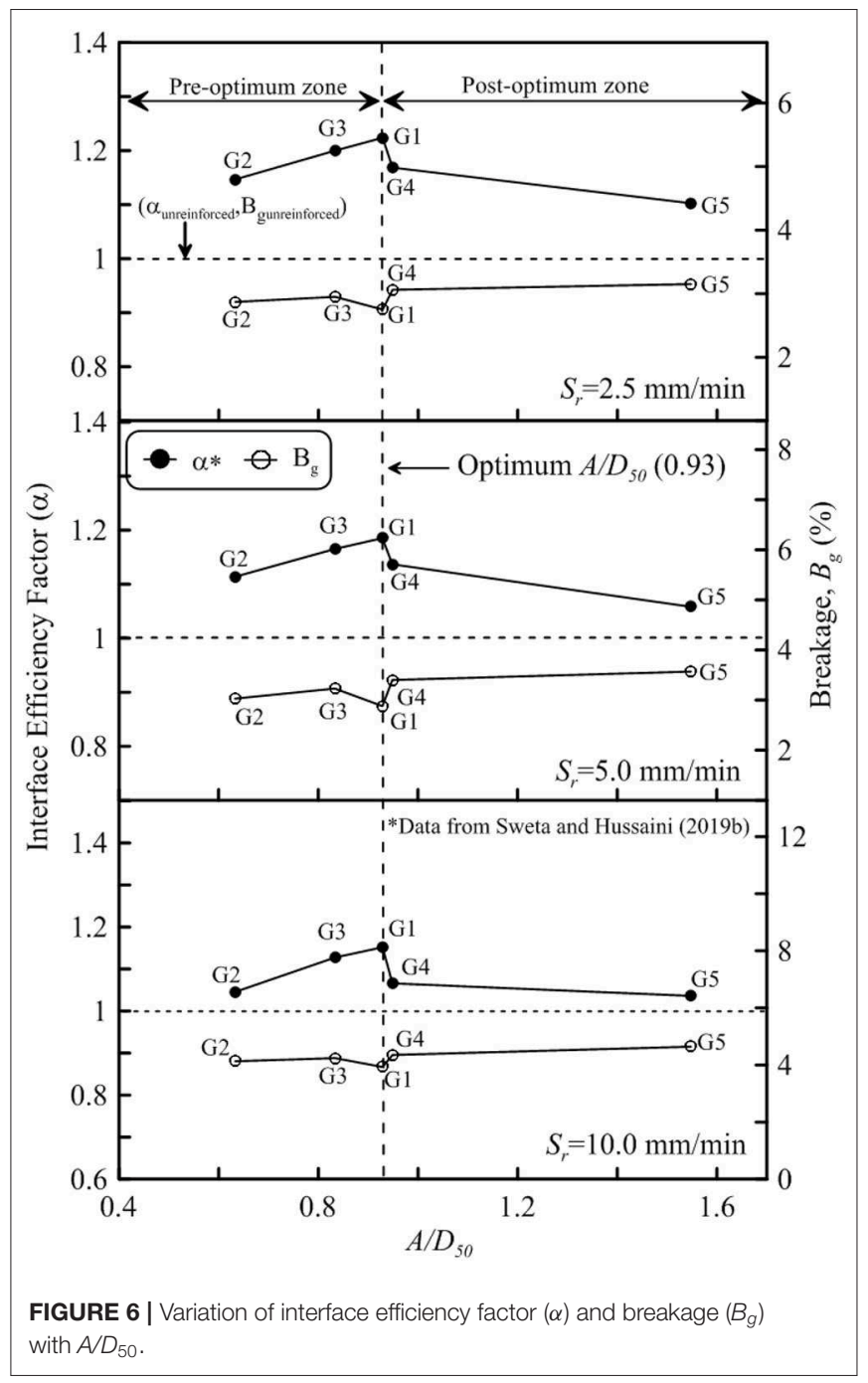

transferred through the wheels of the trains while the confining pressure is generated due to particle-particle interaction, sleeper resistance, compaction stresses and overburden pressure. Moreover, a track under operating conditions will be often subjected to varying train speeds. Therefore, the field conditions are replicated in the laboratory, by suitably considering the values of applied normal stress and the rate of shearing (Sweta and Hussaini, 2019a). Moreover, the performance of a reinforced railway track depends upon the ratio of aperture size $(A)$ of geogrids and the mean particle sizes, $A / D_{50}$ ratio (Indraratna et al., 2012; Sweta and Hussaini, 2018, 2019a,b). In this context, regression models are developed to determine the values of friction angle $(\varphi)$, dilation angle $(\psi)$ and breakage of ballast $\left(B_{g}\right)$ in terms of the input parameters $\sigma_{n}, S_{r}$, and $A / D_{50}$ (Equations 2$7)$. Based on the variation of $\alpha$, the $A / D_{50}$ is classified into two zones (i.e., pre-optimum and post-optimum zone) as shown in Figure 6. The pre-optimum zone lies in the range of $0.63 \leq A / D_{50}$ $\leq 0.93$ while the post-optimum zone lies in the range of $0.93 \leq$ $\bar{A} / D_{50} \leq 1.54$. The $R^{2}$ values for the models presented here vary from 0.88 to 0.90 . 
For $0.63 \leq A / D_{50} \leq 0.93$ :

$$
\begin{aligned}
\varphi & =-0.17 \sigma_{n}-0.55 S_{r}+4.41 A / D_{50}+66.19 \\
\psi & =-0.07 \sigma_{n}-0.19 S_{r}-0.82 A / D_{50}+13.33 \\
B_{g} & =0.01 \sigma_{n}+0.17 S_{r}-0.36 A / D_{50}+1.96
\end{aligned}
$$

For $0.93 \leq A / D_{50} \leq 1.54$

$$
\begin{aligned}
\varphi & =-0.15 \sigma_{n}-0.52 S_{r}-0.26 A / D_{50}+68.36 \\
\psi & =0.06 \sigma_{n}-0.26 S_{r}+0.19 A / D_{50}+13.10 \\
B_{g} & =0.01 \sigma_{n}+0.18 S_{r}+0.67 A / D_{50}+0.97
\end{aligned}
$$

Where $\varphi=$ friction angle, $\psi=$ dilation angle, $B_{g}=$ breakage, $\sigma_{n}=$ applied normal stress, $S_{r}=$ rate of shearing.

The models presented here will help the rail practitioners to predict the values of $\varphi, \psi$, and $B_{g}$ for ballast under both unreinforced and reinforced conditions once the values of input parameters $\left(\sigma_{n}, S_{r}\right.$, and $\left.A / D_{50}\right)$ are known.

\section{Lateral Displacement $\left(I_{d}\right)$ and Vertical Settlement $\left(\mathbf{S}_{\mathrm{v}}\right)$ of Ballast During Cyclic Loading}

The evolution of lateral displacement $\left(l_{d}\right)$ and vertical settlement $\left(S_{v}\right)$ with number of load cycles $(N)$ in case of unreinforced and geogrid-reinforced ballast at $f=30 \mathrm{~Hz}$ is shown in Figure 7 . It is observed that the extent of $l_{d}$ and $S_{v}$ increases rapidly during the initial load applications (i.e., for values of $N$ up to 50,000 cycles), and thereafter the displacements remain mostly the same. However, the extent of $l_{d}$ and $S_{v}$ of ballast reduces with the inclusion of geogrids. For example, insertion of geogrids G1 and G3 reduces the amount of $l_{d}$ and $S_{v}$ by $41 \& 30 \%$ and $33 \& 24 \%$, respectively, in comparison to unreinforced ballast. On the other hand, the geogrid G5 reduces the values of $l_{d}$ and $S_{v}$ by $8 \%$ only. This is because the aperture sizes of geogrids G1 and G3 are nearer to the average particle size of ballast $\left(D_{50}: 42 \mathrm{~mm}\right)$ that ensures effective interlocking of particles thus reducing both $l_{d}$ and $S_{v}$. On the other hand, geogrid G5 having larger apertures facilitates the free movement of particles within the aperture of the geogrids. The almost constant values of $l_{d}$ and $S_{v}$ for $N>50,000$ in case of reinforced samples (Figure 7) indicate that the effectiveness of ballast-geogrid interlock remains unaffected upon repeated load applications. In a practical sense, this implies that once the required ballast-geogrid interlock is accomplished, the geogrid continues to perform its intended purpose of arresting the lateral displacement and thus reducing the vertical settlement of ballast even at 250,000 load cycles. However, the results indicated that the extent of $l_{d}$ and $S_{v}$ increases with the increase in loading frequency but the same are not shown here for the sake of brevity.

\section{Role of Geogrid Aperture Size on the Deformation of Ballast}

To highlight the role of geogrid aperture size, the variation of final lateral displacement $\left(l_{d}\right)$ and vertical settlement $\left(S_{v}\right)$ is plotted against $A / D_{50}$, the ratio of geogrid aperture size to the average particle size of ballast (Figure 8). Figure 8A shows the variation

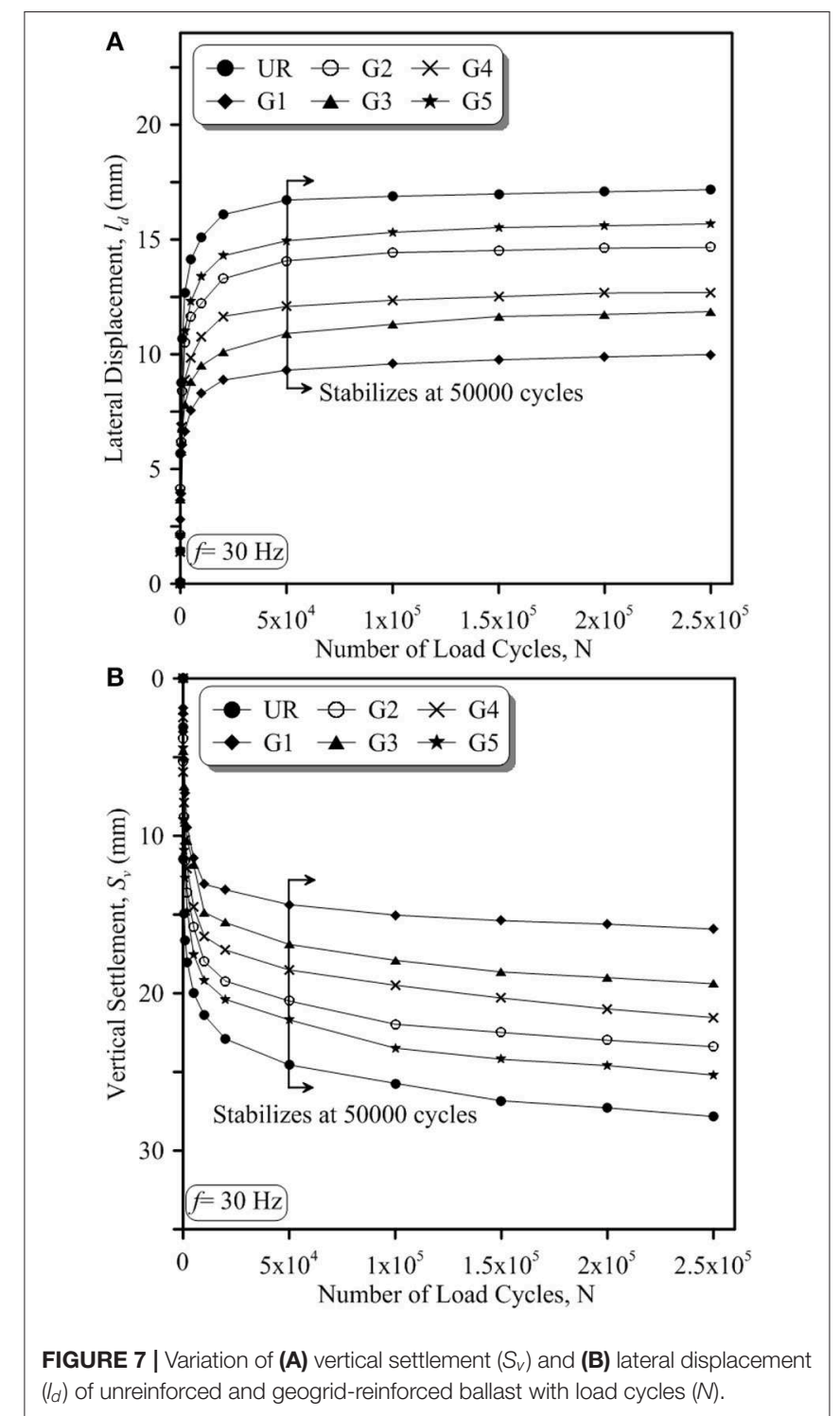

of $l_{d}$ of ballast along the depth of ballast layer as measured at levels of five movable plates with $A / D_{50}$ for $f=30 \mathrm{~Hz}$. It is revealed that the placement of geogrids at the ballast-sub-ballast interface has shown negligible effect in arresting the lateral displacements at the level of top three plates. However, inclusion of geogrids shows a remarkable effect in reducing the lateral displacements of the bottom two plates. These observations establish beyond doubt the diminishing role of geogrid in arresting particle movements away from its placement position. The role of $A / D_{50}$ is thus evident in the near vicinity of geogrid placement position (i.e., for the bottom two plates). In case of the bottom most plate, the value of $l_{d}$ decreases from 14.65 to $9.99 \mathrm{~mm}$ as $A / D_{50}$ increases from 0.63 to 0.93 which again increases to $15.68 \mathrm{~mm}$ at $A / D_{50}$ of 1.54 . An increase in lateral displacement at $A / D_{50}$ of 1.54 subsequent to the minimum lateral displacement at $A / D_{50}$ of 0.93 is mainly due to free movement of the particles within the aperture of geogrids.

Figures 8B,C depicts the variation of lateral displacement $\left(l_{d}\right)$ and vertical settlement $\left(S_{v}\right)$ of ballast with $A / D_{50}$ for various 


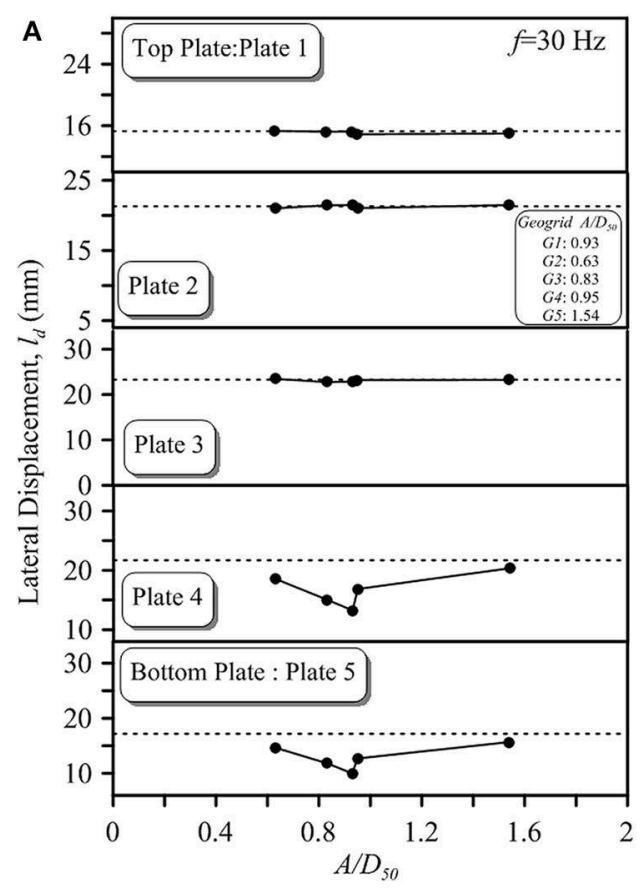

C

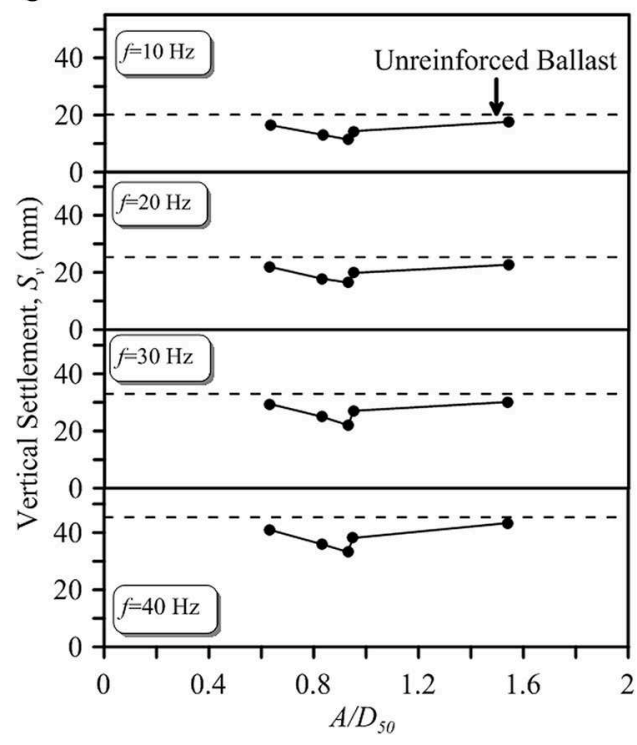

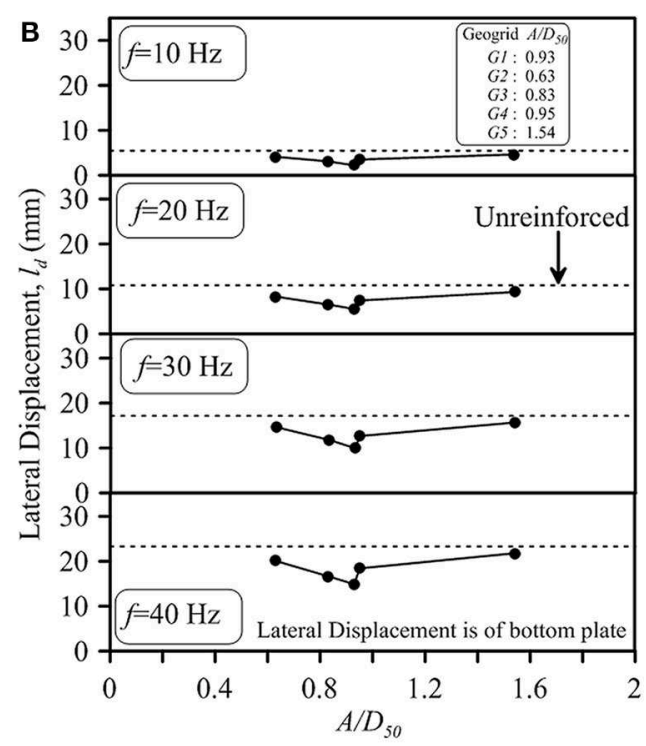



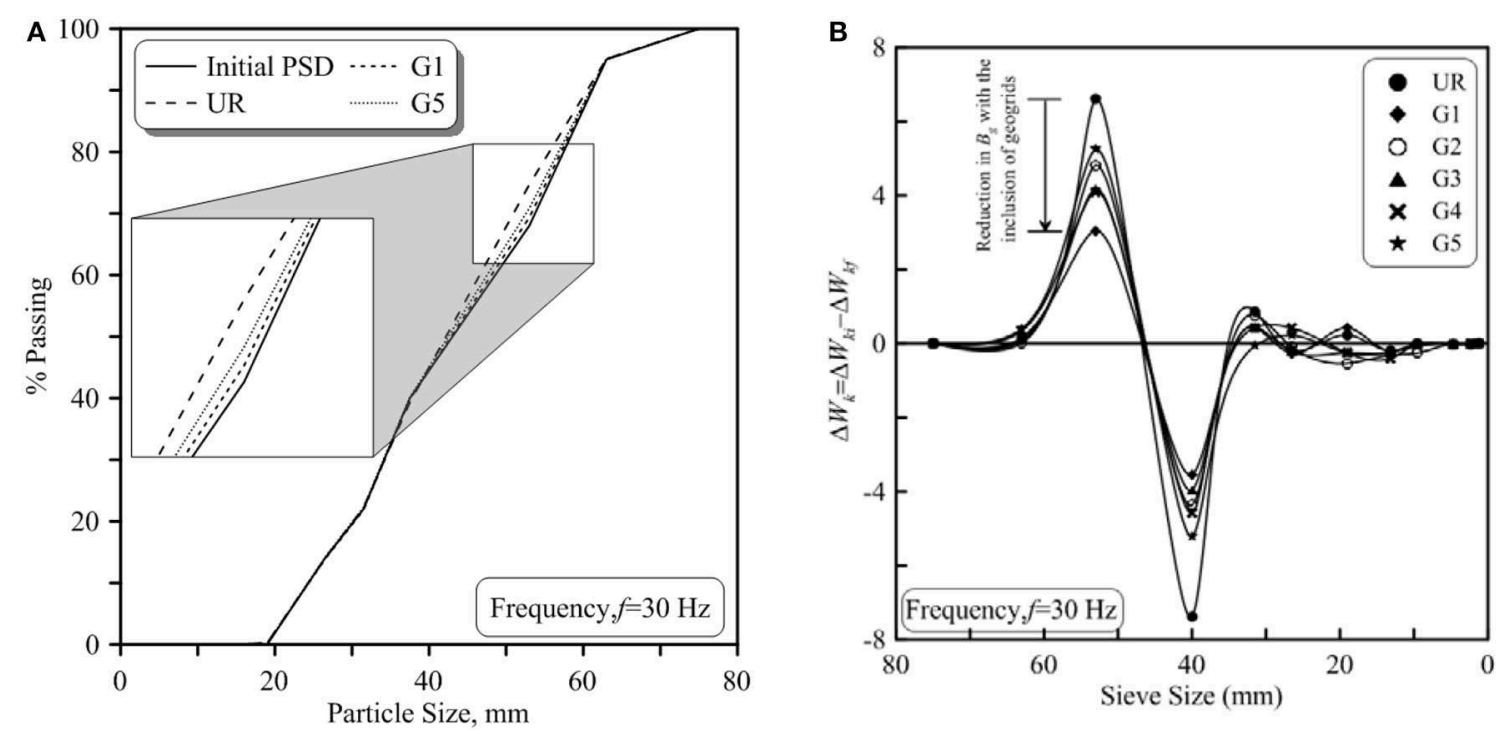

FIGURE 9 | (A) Change in PSD of ballast during cycling loading and (B) variation of particle distribution with sieve size for unreinforced and geogrid-reinforced ballast.

ballast lie far away from its initial PSD followed by the final PSD when reinforced with $G 5$ and $G 1$. Although this highlights the role of geogrids in reducing the overall ballast breakage, but its effect on specific particle sizes is seen clearly from Figure 9B that shows the variation of difference in percentage retained before and after the test $\left(\Delta W_{k}\right)$ at $f=30 \mathrm{~Hz}$. It is evident that bigger particles $(>40 \mathrm{~mm})$, due to the presence of natural flaws in them and their tendency to take up higher proportions of applied load, are more susceptible to breakage in comparison to the smaller particles. Further, the effect of various geogrids (G1 to G5) in reducing the extent of breakage in bigger particles is also clearly evident from Figure 9B, thus justifying their use for stabilizing the rail tracks.

\section{CONCLUSIONS}

The current study investigated the shear behavior of geogridreinforced ballast-sub-ballast interface and also the deformation and degradation behavior of geogrid-reinforced ballast under cyclic loading conditions. It was revealed that friction $(\varphi)$ and dilation angles $(\psi)$ of unreinforced ballast-sub-ballast interface reduces from 63.24 to $47.82^{\circ}$ and 14.56 to $5.23^{\circ}$ with the increase in $\sigma_{n}$ and $S_{r}$, respectively. The breakage of ballast $\left(B_{g}\right)$ occurred during shearing was quantified in terms of Marsal's Breakage $\left(B_{g}\right)$. The $B_{g}$ of unreinforced ballast increases from 2.84 to $6.69 \%$ with the increase of $\sigma_{n} \& S_{r}$. The tests results further revealed that inclusion of geogrids enhanced the shear strength of ballastsub-ballast interface. For example, $\varphi$ of unreinforced ballast-subballast interface increased from 61.82 to $66.02^{\circ}$ and $\psi$ decreased from 12.89 to $10.38^{\circ}$ when the ballast-sub-ballast interface was reinforced with geogrid $G 1\left(\sigma_{n}=20 \mathrm{kPa} ; S_{r}=5.0 \mathrm{~mm} / \mathrm{min}\right)$. Moreover, the extent of $B_{g}$ in case of direct shear test decreases from 3.33 to 2.49 and $2.56 \%$ when stabilized with geogrid $G 1$ and G2, respectively $\left(\sigma_{n}=20 \mathrm{kPa} S_{r}=5.0 \mathrm{~mm} / \mathrm{min}\right)$. The interface efficiency factor $(\alpha)$ and $B_{g}$ were found to be function of $A / D_{50}$ ratio. For the set of geogrids tested in the current study, geogrid $G 1$ with an optimum $A / D_{50}$ of 0.93 exhibits the maximum value of $\alpha$ and minimum value of $B_{g}$. Moreover, regression model is developed using multiple linear regression analysis to predict the values of $\varphi, \psi$, and $B_{g}$ in terms of the input parameters $\sigma_{n}, S_{r}$, and $A / D_{50}$ ratio.

The results from the cubical triaxial tests revealed that the deformation and degradation behavior of ballast under cyclic loading conditions was highly influenced by the loading frequency $(f)$. It is shown that the extent of lateral displacement $\left(l_{d}\right)$ and vertical settlement $\left(S_{v}\right)$ increases rapidly during the initial number of load cycles and thereafter it remains constant. The extent of $l_{d}$ and $S_{v}$ of unreinforced ballast increases from 5.48 to $28.32 \mathrm{~mm}$ and 20.13 to $45.40 \mathrm{~mm}$ with the increase in $f$ from 10 to $40 \mathrm{~Hz}$. The value of $B_{g}$ increased from 4.3 to $11.69 \%$ when the value of $f$ was increased from 10 to $40 \mathrm{~Hz}$. It is further revealed that the inclusion of geogrids reduced the extent of $l_{d}$ and $S_{v}$ of ballast and minimized the extent the particle breakage during cyclic loading. For instance, insertion of geogrid $G 1$ reduces the extent of $l_{d}$ and $S_{v}$ by 42 and 33\%, respectively. The current study showed the benefits of geogrids in enhancing the shear strength and also in reducing the deformation and degradation of ballast particles.

\section{DATA AVAILABILITY STATEMENT}

All datasets generated for this study are included in the article/supplementary material.

\section{AUTHOR CONTRIBUTIONS}

$\mathrm{SH}$ and KS have contributed in the preparation of this manuscript. 


\section{REFERENCES}

Afzali-Nejad, A., Lashkari, A., and Shourijeh, P. T. (2017). Influence of particle shape on the shear strength and dilation of sand-woven geotextile interfaces. Geotext. Geomembr. 45, 54-66. doi: 10.1016/j.geotexmem.2016.07.005

Anubhav and Basudhar, P. K. (2010). Modeling of soil-woven geotextile interface behavior from direct shear test results. Geotext. Geomembr. 28, 403-408. doi: 10.1016/j.geotexmem.2009.12.005

Anubhav and Basudhar, P. K. (2013). Interface behavior of woven geotextile with rounded and angular particle sand. J. Mater. Civ. Eng. 25, 1970-1974. doi: 10.1061/(ASCE)MT.1943-5533.0000774

Atalar, C., Das, B. M., Shin, E. C., and Kim, D. H. (2001). "Settlement of geogrid-reinforced railroad bed due to cyclic load," in Proceedings of 15th International Conference on Soil Mechanics and Geotechnical Engineering (Istanbul), 2045-2048.

Bathurst, R. J., and Raymond, G. P. (1987). Geogrid reinforcement of ballasted track. Transport. Res. Rec. 1153, 8-14.

Biabani, M. M., and Indraratna, B. (2015). An evaluation of the interface behavior of rail sub-ballast stabilized with geogrids and geomembranes. Geotext. Geomembr. 43, 240-249. doi: 10.1016/j.geotexmem.2015.04.002

Biabani, M. M., Indraratna, B., and Ngo, N. T. (2016). Modelling of geocellreinforced sub-ballast subjected to cyclic loading. Geotext. Geomembr. 44, 489-503. doi: 10.1016/j.geotexmem.2016.02.001

Bolton, M. D. (1986). The strength and dilatancy of sands. Geotechnique 36, 65-78. doi: 10.1680/geot.1986.36.1.65

Brown, S. F., Kwan, J., and Thom, N. H. (2007). Identifying the key parameters that influence geogrid reinforcement of railway ballast. Geotext.Geomembr. 25, 326-335. doi: 10.1016/j.geotexmem.2007.06.003

Chen, X., Jia, Y., and Zhang, J. (2018). Stress-strain response and dilation of geogrid reinforced coarse grained soils in large scale direct shear tests. Geotech. Test. J. 41, 1-10. doi: 10.1520/GTJ20160089

Choudhary, A. K., and Krishna, A. M. (2016). Experimental investigation of interface behaviour of different types of granular soil/geosynthetics. Int. J. Geosynth. Ground Eng. 2, 1-11. doi: 10.1007/s40891-016-0044-8

Guler, E., and Khosrowshahi, S. K. (2017). Evaluation of geosynthetic reinforcement on railroad subgrade. Proc. Eng. 189, 721-728. doi: 10.1016/j.proeng.2017.05.114

Hussaini, S. K. K. (2013). An experimental study on the deformation Behavior of geosynthetically reinforced ballast (Ph.D. thesis). Wollongong: University of Wollongong, Australia.

Hussaini, S. K. K., Indraratna, B., and Vinod, J. S. (2012). "Performance of geosynthetically reinforced rail ballast in direct shear conditions," in 11th Australia New Zealand Conference on Geomechanics: Ground Engineering in a Changing World, eds G.A. Narsilo, A. Arulrajah, and J. Kodikara (Melbourne, VIC: Engineers Australia), 1268-1273.

Hussaini, S. K. K., Indraratna, B., and Vinod, J. S. (2015a). Application of optical fiber bragg grating sensors in monitoring the rail track deformations. Geotech. Test J. 38, 387-396. doi: 10.1520/GTJ20140123

Hussaini, S. K. K., Indraratna, B., and Vinod, J. S. (2015b). Performance assessment of geogrid reinforced rail road ballast during cyclic loading. Transport. Geotech. 2, 99-107. doi: 10.1016/j.trgeo.2014.11.002

Hussaini, S. K. K., Indraratna, B., and Vinod, J. S. (2016). A laboratory investigation to assess the functioning of railway ballast with and without geogrids. Transport. Geotech. 6, 45-54. doi: 10.1016/j.trgeo.2016.02.001

Indraratna, B., Biabani, M. M., and Nimbalkar, S. (2015). Behavior of geocell-reinforced sub-ballast subjected to cyclic loading in plane-strain condition. J. Geotech. Geoenviron. Eng. 141:04014081. doi: 10.1061/(ASCE)GT.1943-5606.0001199

Indraratna, B., Hussaini, S. K. K., and Vinod, J. S. (2012). On the shear behavior of ballast-geosynthetic interfaces. Geotech. Test. J. 35, 305-312. doi: 10.1520/GTJ103317

Indraratna, B., Hussaini, S. K. K., and Vinod, J. S. (2013). The lateral displacement response of geogrid-reinforced ballast under cyclic loading. Geotext. Geomembr. 39, 20-29. doi: 10.1016/j.geotexmem.2013.07.007

Indraratna, B., Shanin, M. A., and Salim, W. (2007). Stabilisation of granular media and formation soil using geosynthetics with special reference to railway engineering. Proc. Inst. Civ. Eng. Ground Improv. 11, 27-43. doi: 10.1680 /grim.2007.11.1.27
Indraratna, B., Thakur, P. K., and Vinod, J. S. (2010). Experimental and numerical study of railway ballast behavior under cyclic loading. Int. J. Geomech. 10, 136-144. doi: 10.1061/(ASCE)GM.1943-5622.0000055

IRSGE (2004). Specifications for Track Ballast. Research Design and Standard Organisation (RDSO), Ministry of Railways, India.

Jeffs, T., and Tew, G. P. (1991). A Review of Track Design Procedures: Sleepers and Ballast, Vol. 2. Melbourne, VIC: Railways of Australia.

Lee, K. M., and Manjunath, V. R. (2000). Soil-geotextile interface friction by direct shear tests. Can. Geotech. J. 37, 238-252. doi: 10.1139/t99-124

Liu, C. N., Ho, Y. H., and Huang, J. W. (2009). Large-scale direct shear tests of soil/PET yarn geogrid interfaces. Geotext. Geomembr. 27, 19-30. doi: 10.1016/j.geotexmem.2008.03.002

Liu, F.-Y., Wang, P., Geng, X., Wang, J., and Lin, X. (2016). Cyclic and post-cyclic behavior from sand-geogrid interface large-scale direct shear tests. Geosynth. Int. 23, 129-139. doi: 10.1680/jgein.15.00037

Liu, H., and Martinez, J. (2015). Creep behavior of sand-geomembrane interfaces. Geosynth. Int. 21, 83-88. doi: 10.1680/gein.13.00036

Liu, S., Huang, H., Qiu, T., and Kwon, J. (2016). Effect of geogrid on railroad ballast particle movement. Transport. Geotech. 9, 110-122. doi: 10.1016/j.trgeo.2016.08.003

Makkar, F. M., Chandrakaran, S., and Sankar, S. (2017). Performance of 3-D geogrid reinforced sand under direct shear mode. Int. J. Geotech. Eng. 13, 227-235. doi: 10.1080/19386362.2017.1336297

Matharu, M. S. (1994). Geogrid cut ballast settlement rate on soft substructures. Railway Gazette Int. 150, 165-166.

Mirzaalimohammadi, A., Ghazavi, M., Roustaei, M., and Lajewardi, S. H. (2019). Pullout response of strengthened geosynthetic interacting with fine sand. Geotext. Geomembr. 47, 530-541. doi: 10.1016/j.geotexmem.2019.02.006

Mishra, D., Qian, Y., Kazmee, H., and Tutumluer, E. (2014). Investigation of geogrid-reinforced railroad ballast behavior using large-scale triaxial testing and discrete element modeling. Transport. Res. Board. 2462, 98-108. doi: $10.3141 / 2462-12$

Moraci, N., Cardile, G., Gioffrè, D., Mandaglio, M. C., Calvarano, S. M., and Carbone, L. (2014). Soil geosynthetic interaction: design parameters from experimental and theoretical analysis. Transport. Infrastr. Geotech. 1, 165-227. doi: 10.1007/s40515-014-0007-2

Mvelase, M. G., Grabe, P. J., and Anochie-Boateng, J. K. (2017). The use of laser technology to investigate the effect of railway ballast roundness on shear strength. Transport. Geotech. 11, 97-106. doi: 10.1016/j.trgeo.2017. 05.003

Navaratnarajah, S. K., and Indraratna, B. (2017). Use of rubber mats to improve the deformation and degradation behavior of rail ballast under cyclic loading. J. Geotech. Geoenviron. Eng. 143:04017015 doi: 10.1061/(ASCE)GT.1943-5606.0001669

Nimbalkar, S., and Indraratna, B. (2016). Improved performance of ballasted rail track using geosynthetics and rubber shock mats. J. Geootech. Geoenviron. Eng. 142:04016031. doi: 10.1061/(ASCE)GT.1943-5606.0001491

Palmeira, E. M. (2009). Soil-geosynthetic interaction: modeling and analysis. Geotext. Geomembr. 27, 368-390. doi: 10.1016/j.geotexmem.2009. 03.003

RDSOGE (2007). Guidelines for Blanket Layer Provision on Track Formation. Research Design and Standard Organisation (RDSO), Ministry of Railways, India.

Sayeed, M. M. A., Ramaiah, B. J., and Rawal, A. (2014). Interface shear characteristics of jute/polypropylene hybrid nonwoven geotextiles and sand using large size direct shear test. Geotext. Geomembr. 42, 63-68. doi: 10.1016/j.geotexmem.2013.12.001

Shin, E. C., Kim, D. H., and Das, B. M. (2002). Geogrid-reinforced railroad bed settlement due to cyclic load. Geotech. Geol. Eng. 20, 261-271. doi: 10.1023/A:1016040414725

Simoni, A., and Houlsby, G. T. (2006). The direct shear strength and dilatancy of sand-gravel mixtures. Geotech. Geol. Eng. 24, 523-549. doi: 10.1007/s10706-004-5832-6

Sun, Q., Indraratna, B., and Ngo, N. T. (2019). Effect of increase in load and frequency on the resilience of railway ballast. Geotechnique 69, 833-840. doi: 10.1680/jgeot.17.P.302

Sun, Q., Indraratna, B., and Nimbalkar, S. (2014). Effect of cyclic loading frequency on the permanent deformation and degradation 
of railway ballast. Geotechnique 64, 746-751. doi: 10.1680/geot. 14.T.015

Sweta, K., and Hussaini, S. K. K. (2018). Effect of shearing rate on the behavior of geogrid-reinforced railroad ballast under direct shear conditions. Geotext. Geomembr. 46, 251-256. doi: 10.1016/j.geotexmem.2017.12.001

Sweta, K., and Hussaini, S. K. K. (2019a). Performance of geogrid-reinforced railroad ballast in direct shear mode. Proc. Inst. Civ. Eng. Ground Improv. 172, 244-256 doi: 10.1680/jgrim.18.00107

Sweta, K., and Hussaini, S. K. K. (2019b). Behavior evaluation of geogridreinforced ballast-sub-ballast under shear conditions. Geotext. Geomembr. 47, 23-31. doi: 10.1016/j.geotexmem.2018.09.002

Thakur, P. K., Vinod, J. S., and Indraratna, B. (2013). Effect of confining pressure and frequency on the deformation of ballast. Geotechnique 63, 786-790. doi: 10.1680/geot.12.T.001
Vieira, C. S., Lopes, M. L., and Caldeira, L. M. (2015). Sand-geotextile interface characterization through monotonic and cyclic direct shear tests. Geosynth. Int. 20, 26-38. doi: 10.1680/gein.12.00037

Conflict of Interest: The authors declare that the research was conducted in the absence of any commercial or financial relationships that could be construed as a potential conflict of interest.

Copyright (c) 2020 Hussaini and Sweta. This is an open-access article distributed under the terms of the Creative Commons Attribution License (CC BY). The use, distribution or reproduction in other forums is permitted, provided the original author(s) and the copyright owner(s) are credited and that the original publication in this journal is cited, in accordance with accepted academic practice. No use, distribution or reproduction is permitted which does not comply with these terms. 


\section{NOMENCLATURE}

$\begin{array}{ll}A & \text { Aperture Size } \\ B_{g} & \text { Marsal's Breakage Index } \\ C_{C} & \text { Coefficient of Curvature } \\ C_{u} & \text { Coefficient of Uniformity } \\ D_{\max } & \text { Maximum particle size } \\ D_{50} & \text { Average particle size } \\ f & \text { Loading frequency } \\ l_{d} & \text { Lateral displacement } \\ \varepsilon_{3} & \text { Lateral strain } \\ \alpha & \text { Interface efficiency factor } \\ \phi & \text { Friction angle } \\ \delta & \text { Apparent friction angle for ballast geogrid interface } \\ \psi & \text { Dilation angle } \\ \gamma_{b} & \text { Density of ballast } \\ \gamma_{s b} & \text { Density of sub-ballast } \\ \sigma_{n} & \text { Applied normal stress } \\ N & \text { Number of load cycles } \\ P S D & \text { Particle size distribution } \\ S_{r} & \text { Shearing rate } \\ S_{V} & \text { Vertical settlement } \\ T_{u l t} & \text { Ultimate tensile strength } \\ \tau_{n} & \text { Shear stress } \\ W_{k} & \text { Percentage weight retained } \\ & \end{array}$

